\title{
Sistem Pendukung Keputusan Evaluasi Kinerja Pegawai pada Dinas Pekerjaan Umum Bengkulu Selatan Menggunakan Simple Additive Weighting Method
}

\author{
Yuza Reswan ${ }^{1}$, Dedy Agung Prabowo ${ }^{2}$ \\ ${ }^{1}$ Dosen Tetap Program Studi Teknik Informatika, Universitas Muhammadiyah Bengkulu \\ Jl. Balai Po.Box. 118 Telp. (0736) 22765. Fax. (0736) 26161 Bengkulu 38119; e-mail: yuzareswan@umb.ac.id \\ ${ }^{2}$ Dosen Tetap Program Studi Sistem Informasi, Universitas Muhammadiyah Bengkulu \\ Jl. Balai Po.Box. 118 Telp. (0736) 22765. Fax. (0736) 26161 Bengkulu 38119; e-mail: dedyagungprabowo@umb.ac.id
}

\begin{abstract}
The decision support system of employee performance evaluation in the general work service department of south Bengkulu is very useful because it can give the alternatives for making decision in choosing the appropriate employees to fill a vacant position. The use of the decision support system of the performance evaluation of public work service employees by using simple additive method are expected to eliminate the subjectivity in making decisions. Instead, calculation will be made on all employees assessments, so that the employees with the best abilities are expected to be chosen. The objective of the study is to make the decision support system of employee performance evaluation in Public Works Service Department of South Bengkulu. The benefit of the study is to give alternatives for the decision makers to choose the appropriate employees to fill the vacant position.

Keywords: Decision Support System, employee Performance Evaluation
\end{abstract}

Intisari-Sistem pendukung keputusan evaluasi kinerja pegawai pada dinas pekerjaan umum Bengkulu Selatan sangat bermanfaat karena dapat memberikan Alternatif lain bagi para pengambil keputusan untuk memilih pegawai yang cocok untuk mengisi jabatan yang kosong. Penggunaan sistem pendukung keputusan evaluasi kinerja pegawai dengan metode simple additive weighting diharapkan mengurangi subjektifitas dalam pengambilan keputusan. Sebagai gantinya akan dilakukan perhitungan terhadap seluruh penilaian pegawai, sehingga diharapkan pegawai dengan kemampuan terbaiklah yang terpilih. Penelitian bertujuan membuat sistem pendukung keputusan evaluasi kinerja public service pegawai pada dinas pekerjaan umum Bengkulu selatan. Manfaat dari penelitian ini dapat memberikan alternatif lain bagi para pengambil keputusan untuk memilih pegawai yang cocok untuk mengisi jabatan yang kosong.

Kata Kunci : Sistem Pendukung Keputusan, Evaluasi Kinerja Pegawai.

\section{Pendahulaun}

Perkembangan teknologi informasi pada zaman sekarang ini meningkat dengan pesat dan memungkinkan kita mendapatkan informasi secara cepat, tepat dan efisien serta mempunyai manfaat yang sangat besar. Kebutuhan akan informasi semakin meningkat sesuai dengan kebutuhannya, hal ini ditunjukkan dengan banyaknya penerapan aplikasi sistem informasi pada lembaga, perusahaan dan instansi lainnya. Berbagai kepentingan menjadi dasar pertimbangan, dari mulai lifestyle atau pelengkap sampai dengan menjadi perangkat dan sarana yang menempati posisi yang vital[1]. Kualitas sumber daya manusia merupakan salah satu faktor yang diperlukan untuk meningkatkan produktivitas kinerja suatu instansi. Oleh karena itu diperlukan sumber daya manusia yang mempunyai kompetensi tinggi karena keahlian atau kompetensi akan dapat mendukung peningkatan prestasi kerja pegawai.

Penilaian kinerja harus dilakukan untuk mengetahui prestasi yang dapat dicapai setiap pegawai. Dengan melakukan proses penilaian kinerja maka prestasi yang dicapai setiap pegawai dengan nilai baik sekali, baik, cukup atau kurang bisa diketahui. Penilaian prestasi penting bagi setiap pegawai dan berguna bagi instansi untuk menetapkan tindakan kebijaksanaan selanjutnya.

Penilaian kinerja digunakan untuk mengevaluasi hasil kerja seluruh pegawai secara kuantitatif dan kualitatif dengan menggunakan kriteria komitmen yang dinilai jujur, loyal, tanggung jawab dan disiplin. Manajemen yang dinilai kepemimpinan, perencanaan, pengorganisasian dan pengarahan. Kerjasama yang dinilai komunikasi, beradaptasi dan berbagi informasi. Hasil kerja yang dinilai adalah kualitas dan kuantitas.

Banyaknya kriteria (multiplecriteria) yang digunakan dalam proses penilaian kinerja pegawai menyulitkan pihak manajemen untuk memberi bobot setiap kriteria oleh karena itu dibutuhkan suatu metode 
yang tepat, adapun metode yang digunakan untuk menyelesaikan multiple criteria di Dinas Pekerjaan UmumBengkulu Selatan dengan menggunakan Simple additive weighting method (SAW). Selain multi kriteria pihak manajemen juga menginginkan sistem yang mampu mengatasi bila suatu saat ada perubahan jumlah dan nama kriteria

\section{LANDASAN TEORI}

\section{A. Konsep Dasar Sistem Pendukung Keputusan}

Konsep dasar sistem pendukug keputusan sebagai sebuah sistem berbasis komputer yang membantu dalam proses pengambilan keputusan. SPK sebagai sistem informasi berbasis komputer yang adaptif, interaktif, fleksibel dan secara khususnya di kembangkan untuk mendukung solusi dari permasalahan manajemen yang tidak terstruktur untuk meningkatkan kualitas pengambilan keputusan. Dengan demikian dapat di tarik satu definisi SPK yaitu sebuah sistem berbasis komputer yang adaptif, fleksibel dan interaktif yang di gunakan untuk memecahkan maalah yang tidak terstruktur hingga meningkatkan nilai keputusan yang diambil.

\section{B. Sistem Pendukung Keputusan (Decision Support System)}

Teori tentang pengambilan keputusan organisasi dikembangkan di Carnegie Institute of Technology (akhir tahun 1950an - awal tahun 1960an). Implementasi DSS tersebut dalam bentuk sistem komputer interaktif dilakukan di Massachusetts Institute of Technology (tahun 1960an). Konsep DSS menjadi area riset (pertengahan 1970 - 1980an). Dikembangkan executive information systems (EIS), group decision support systems (GDSS), dan organizational decision support systems (ODSS) untuk single user berbasis model (pertengahan 1980). Dikembangkan data warehousing dan on-line analytical processing (OLAP) (awal tahun 1990). Dikembangkan aplikasi analitik berbasis web [2].

Istilah SPK mengacu pada suatu sistem yang memanfaatkan dukungan komputer dalam proses pengambilan keputusan. Untuk memberikan pengertian yang lebih mendalam, akan diuraikan beberapa difinisi mengenai SPK yang dikembangkan oleh beberapa ahli, diantaranya:

1. Sistem pendukung keputusan adalah sistem yang memiliki kemampuan dalam mendukung analisis data dan pemodelan keputusan dengan berorientasi pada perencanaan masa depan dan digunakan dalam jangka waktu yang tak tentu[3].

2. Sistem Pendukung Keputusan/ Decision support Sistem (DSS) merupakan sistem informasi interaktif yang menyediaka informasi, pemodelan dan pemanipulasian data. Sistem itu digunakan untuk membantu pengambilan keputusan dalam situasi yangsemiterstruktur dan situasi yang tidak terstruktur, dimana tak seorang pun tahu secara pasti bagaimana keputusan seharusnya[4].

DSS biasanya dibangun untuk mendukung solusi atas sustu masalah atu untuk mengevaluasi suatu peluang. DSS yang seperti itu disebut aplikasi DSS.Aplikasi DSS digunakan dalam pengambilan keputusan.Aplikasi DSS menggunakan CBIS (Computer Based Informasion Systems) yang fleksibel, interaktif, dan dapat diadaptasi, yang dikembangkan untuk mendukung solusi atas masalah manajemen spesifik yang tidak terstruktur[5].

Aplikasi DSS menggunakan data, memberikan antarmuka pengguna yang mudah, dan dapat menggabungkan pemikiran pengambil keputusan.DSS lebih ditujukan untuk mendukung manajemen dalam melakukan pekerjaan yang bersifat analitis dalam situasi yang kurang terstruktur dan dengan kriteria yang kurang jelas.DSS tidak dimaksudkan untuk mengotomatiskan pengambilan keputusan, tetapi memberikan perangkat interaktif yang memungkinkan pengambil keputusan untuk melakukan berbagai analisis menggunakan model yang tersedia[5].

\section{Evaluasi Kinerja Pegawai}

Evaluasi kinerja adalah suatu metode dan proses penilaian dan pelaksanaan tugas seseorang atau sekelompok orang atau unit-unit kerja dalam satu perusahaan atau organisasi sesuai dengan standar kinerja atau tujuan yang ditetapkan lebih dahulu. Evaluasi kinerja 
merupakan cara yang paling adil dalam memberikan imbalan atau penghargaan kepada pekerja[6].

Tujuan evaluasi kinerja adalah untuk menjamin pencapaian sasaran dan tujuan perusahaan dan juga untuk mengetahui posisi perusahaan dan tingkat pencapaian sasaran perusahaan, terutama untuk mengetahui bila terjadi keterlambatan atau penyimpangan supaya segera diperbaiki, sehingga sasaran atau tujuan tercapai. Hasil evaluasi kinerja individu dapat dimanfaatkan untuk banyak penggunaan

\section{Analisis dan Perancangan}

\section{A. Analisis Sistem}

Pada diagram di bawah ini dapat kita lihat bahwa administrasi menginputkan data pegawai dan melakukan penilaian promosi. Data pegawai di evaluasi dan di lakukan proses penilaian, Kabag menerima dan memutuskan hasil evaluasi kinerja pegawai. Kepala/pimpinan menerima hasil keputusan evaluasi kinerja pegawai dan menyetujui hasil keputusan tersebut.

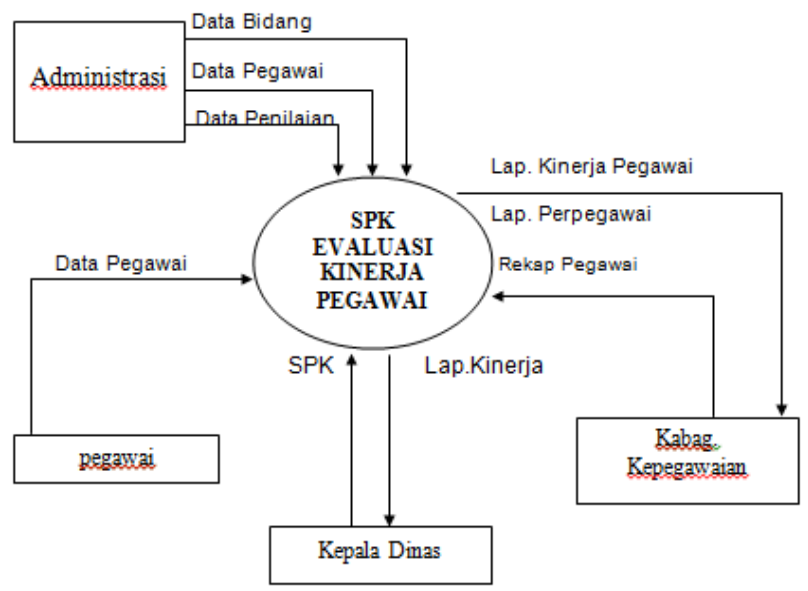

Gambar 1. Konteks Diagram

\section{B. Entity Relation Diagram (ERD)}

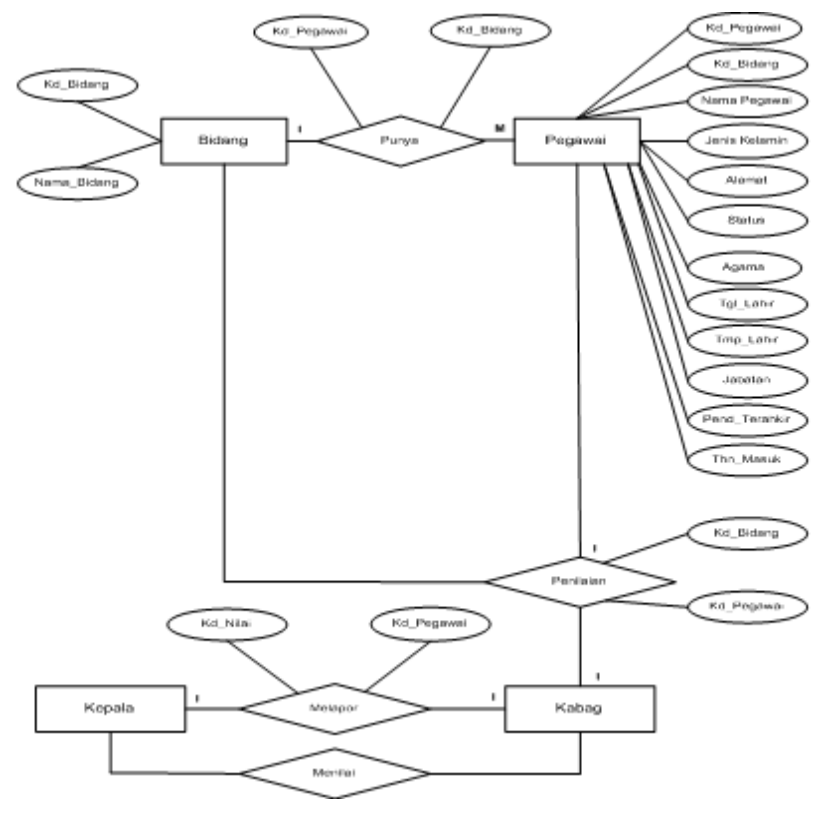

Gambar 2. ERD Sistem

\section{IV.HASIL}

\section{A. Form Login Aplikasi}

Pada Menu Admin ini merupakan menu awal dari Program Sistem Pendukung Keputusan Evaluasi kinerja pegawai pada Dinas Pekerjaan Umum Bengkulu selatan, menu yang pertama kali tampil saat program ini di jalankan, pada menu ini juga terdapat tulisan Sistem Pendukung Keputusan Evaluasi kinerja pegawai pada Dinas Pekerjaan Umum Bengkulu selatan dan juga terdapat menu password dibuat untuk menjaga keamanan dari data-data yang ada dalam program, untuk menggunakan password, operator program dapat mengisikan beberapa digit huruf ataupun angka selanjutnya tekan tombol enter pada keyboard.

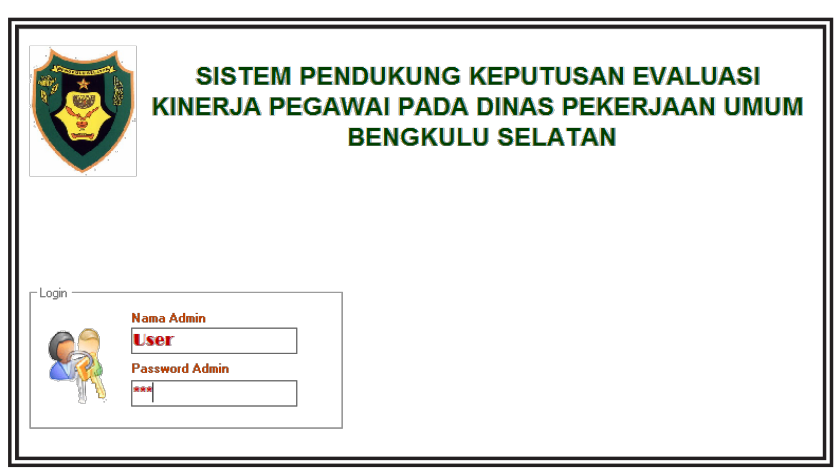

Gambar 3. Tampilan Halaman Login 


\section{B. Form Input Data Penilaian}

Sub menu input data penilaian pegawai ini berfungsi untuk mengolah data penilaian dari pegawai Dinas Pekerjaan Umum Bengkulu selatan dalam menentukan layak tidak layaknya seseorang pegawai untuk menempati jabatan tertentu

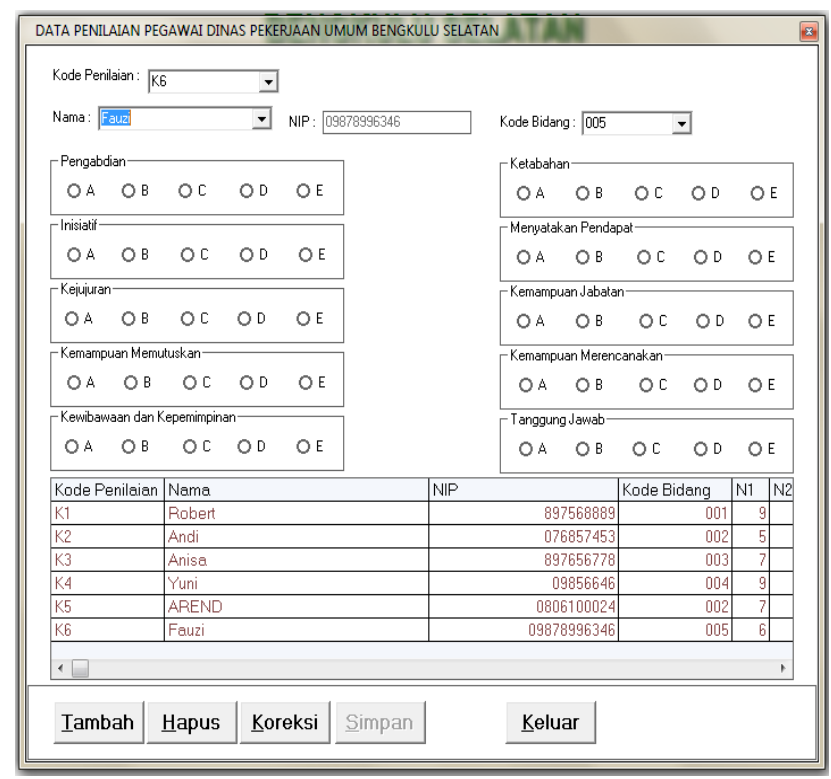

Gambar 4. Form Input Data Penilaian

\section{Form Informasi Penilaian}

Menu informasi ini merupakan data informasi point atau bobot penilaian evaluasi kinerja pegawai di Dinas Pekerjaan Umum Bengkulu Selatan, baik yang akan ditampilkan dalam bentuk media tertulis atau hanya berbentuk keluaran yang ditampilkan dilayar monitor.

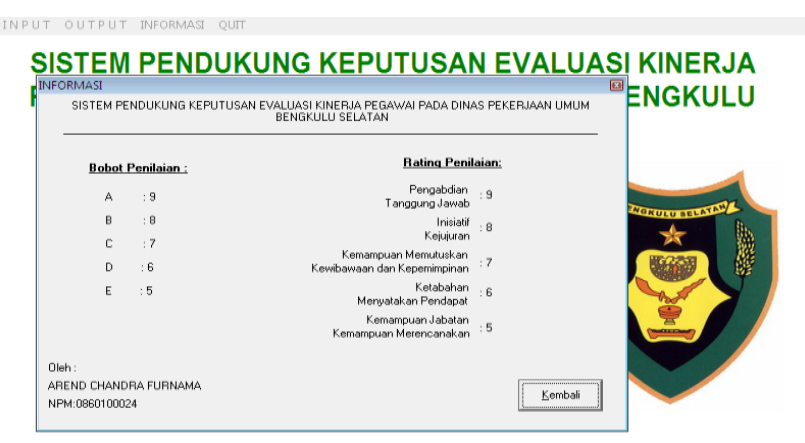

Gambar 5. Halaman Informasi Penilaian

\section{Penutup}

\section{A. Kesimpulan}

1. Dinas Pekerjaan umum Bengkulu Selatan dalam hal pengentrian data belum menggunakan aplikasi khusus, masih menggunakan aplikasi Microsoft excel sebagai dokumentasi filenya, sehingga sering terjadi kekeliruan, lambat proses pengimputan data serta membutuhkan waktu yang lama dalam hal menyusun laporan.

2. Dengan menggunakan program aplikasi sistem pendukung keputusan evaluasi kinerja pegawai pada Dinas Pekerjaan umum Bengkulu Selatan, pengolahan data dan penyajian informasi menjadi lebih jelas, cepat, efektif dan efisien dibandingkan dengan menggunakan aplikasi Microsoft excel, data yang dimasukkan dalam system ini berupa input data bidang, input data pegawai, input data penilaian pegawai.

3. Pada sistem ini selain menginputkan semua data, terdapat laporan merupakan hasil dari pengentrian pada input data, laporan tersebut berupa laporan data pegawai, laporan data evaluasi kinerja pegawai

\section{B. Saran}

1. Hendaknya Dinas Pekerjaan umum Bengkulu Selatan menggunakan system yang bisa memberi masukan dalam mengambil keputusan dan sebaliknya menggunakan pemrograman Visual Basic 6.0 karena lebih mudah dalam databasenya

2. Diharapkan kepada Dinas PU Bengkulu Selatan untuk dapat menggunakan system pengambilan keputusan evaluasi kinerja pegawai dengan menggunakan metode simple additive weighting method (SAW) supaya dapat mempromosikan jabatan pegawai di dinas PU Bengkulu Selatan khususnya pada bidang pengairan.

3. Supaya Sistem Pendukung Keputusan dapat berguna bagi pembaca yang ingin memahami tentang cara kerja SPK, supaya untuk kedepanya dapat membangun program yang lebih baik dan efektif dari sebelumnya 


\section{Daftar Pustaka}

[1] Prabowo, D. A. (2016). Sistem Informasi Pendataan Mahasiswa Menggunakan Fitur Binary Large Object (Blob) Untuk Menyimpan Data Gambar (Studi Kasus: Program Studi Sistem Informasi Universitas Muhammadiyah Bengkulu). Jurnal Pseudocode, 3(1), 10-14.

[2] Moore, J. H., \& Chang, M. G. (1980). Design of decision support systems. ACM SIGMIS Database: the DATABASE for Advances in Information Systems, 12(1-2), 8-14.

[3] Alter, S. (2002). The work system method for understanding information systems and information systems research. Communications of the Association for Information Systems, 9(1), 6.

[4] Kusumadewi, S. (2005). Pencarian Bobot Atribut Pada MultipleAttribute Decision Making dengan Pendekatan Objektif Menggunakan Algoritma Genetika. Universitas Islam Indonesia (UII).

[5] Dhermawan, A. A. N. B., Sudibya, I. G. A., \& Utama, I. W. M. (2012). Pengaruh motivasi, lingkungan kerja, kompetensi, dan kompensasi terhadap kepuasan kerja dan kinerja pegawai di lingkungan kantor Dinas Pekerjaan Umum Provinsi Bali. Matrik: Jurnal Manajemen, Strategi Bisnis dan Kewirausahaan.

[6] Suryadi, K., \& Ramdhani, M. A. (1998). Sistem Pendukung Keputusan. PT Remaja Rosdakarya, Bandung. 